\title{
Genetics and human rights. Two histories: Restoring genetic identity after forced disappearance and identity suppression in Argentina and after compulsory isolation for leprosy in Brazil
}

\author{
Victor B. Penchaszadeh ${ }^{1}$ and Lavinia Schuler-Faccini ${ }^{2,3}$ \\ ${ }^{1}$ Departmento de Ciencias de la Salud, Universidad Nacional de La Matanza, Buenos Aires, Argentina. \\ ${ }^{2}$ Instituto Nacional de Ciencia e Tecnologia em Genetica Médica Populacional, Porto Alegre, RS, Brazil. \\ ${ }^{3}$ Departamento de Genética, Universidade Federal do Rio Grande do Sul, Porto Alegre, RS, Brazil.
}

\begin{abstract}
Over the past three decades, there has been an accelerated development of genetic technology, leading to its use in human genetic identification for many purposes. Additionally, it has been made explicit that identity is a fundamental human right. A number of historical circumstances have connected these developments. Personal identity is increasingly associated with the preservation and defense of human rights and is a tool to repair the violation of these rights, particularly the right to identity. In this article, we report the use of genetics to support the right to identity in two historical circumstances. First, we report the search, localization, DNA testing and genetic identification of 110 individuals who were appropriated as babies by the Argentine military dictatorship of 1976-1983 in the context of savage repression and egregious violations of human rights, including forced disappearance and suppression of identity. Second, we report on the repair of right-to-identity violations of hundreds of individuals that occurred during the process of compulsory isolation of patients with leprosy in Brazil through the Program "Reencontro", which has led to the genetic identification of 158 pairs of individuals who previously did not have proof that they were siblings. The high value placed on genetic identification by victims of identity suppression did not counter the prevailing view that genetic factors were not more important than other factors (social, emotional, educational, cultural, spiritual) in determining the complex phenomenon of personal identity. The use of genetic identification as a tool to redress and repair human rights violations is a novel application of human genetics for the benefit of mankind.
\end{abstract}

Keywords: genetics and human rights, suppression of identity, leprosy, Argentina, Brazil.

\section{Introduction}

Developments in human genetics over the past halfcentury have been unprecedented and to the point that the $21^{\text {st }}$ century has been dubbed "the century of the genome". However, the awesome discoveries and applications of genetic technology should not allow us to forget that flawed genetic concepts were used in the past to justify troubling violations of human rights, such as eugenics, racism, discrimination, stigmatization of those who are "different" and even genocide (Müller-Hill, 1988; Kevles, 1995). More recently, progress in forensic genetics has enabled its use in human genetic identification for different purposes. Additionally, it became explicit that the right of identity is a fundamental human right (United Nations, 1989). A number of historical circumstances have connected these developments, and genetic identification is increasingly associ-

Send correspondence to Victor B. Penchaszadeh. Departmento de Ciencias de la Salud, Universidad Nacional de La Matanza, Florencio Varela 1903, San Justo, Buenos Aires, Argentina. E-mail: victorpenchas@gmail.com. ated with the preservation and defense of human rights, in particular the right to identity, and is an excellent tool to repair the ominous consequences of right-to-identity violations and to bring those responsible to justice (United Nations, 2009).

In this paper we describe two histories that exemplify the use of genetics in the defense of human rights.

\section{Restoration of Genetic Identity After Forced Disappearance and Suppression of Identity in Argentina}

\section{Background}

During the dictatorship that ruled Argentina between 1976 and 1983, the military engaged in savage repression and egregious violations of human rights, including the forced disappearance of 30,000 political dissidents (CONADEP, 1986). The disappeared included pregnant women, babies and small children abducted with their parents. Abducted adults were taken to one of many secret 
detention centers run by the military, where they were savagely tortured and, with few exceptions, murdered. Pregnant women were not spared torture and suffering during their captivity, delivering their babies in humiliating circumstances in military barracks or hospitals, only to be murdered shortly after delivery. It is estimated that no less than 500 babies were born in captivity to disappeared women (Van Boven, 1988; Andersen 1993) and their fate varied: most commonly, they were kept as "war booty" by someone within, or linked to the security forces. Birth certificates were forged, and the children were registered as biological offspring of their appropriators. (Penchaszadeh, 1997). In a few cases, babies were anonymously left in institutions for abandoned children or handed over to neighbors (OAS Organization of American States, 1978). In virtually all of the cases, the children were raised with their true identity suppressed. The appropriation of babies of dissidents was part of a deliberate genocidal military policy based on the perverse conviction that those in power had the duty of "freeing these children from the subversive education" of their parents.

\section{Methodology}

After the return of democracy in 1984, an intensive and prolonged search for the disappeared children began and was led by the Abuelas (grandmothers) of Plaza de Mayo, a non-governmental human rights organization with the specific mission of finding the children of their disappeared sons and daughters. The constitutional government appointed a National Commission on the Disappeared (CONADEP, 1986), which requested the help of the American Association for the Advancement of Sciences (AAAS) to devise a statistical formula to genetically identify children in the absence of their disappeared parents by comparing their genetic markers to those of putative grandparents. Eventually a "grandparentage index" was devised and successfully applied in 1984 to identify the first appropriated child (Di Lonardo et al., 1984; Penchaszadeh, 1997, 2012). Soon, many suspected appropriated children started to be localized through various means (anonymous reports, reports from survivors of detention camps, forged birth certificates, suspicious adoptions and others), and legal procedures for their identification started. All requests for genetic testing were mandated by the courts, after proper legal, ethical and psychological handling of each suspected case.

The National Bank of Genetic Data (BNDG, by its initials in Spanish), created by law in 1987, developed a database using genetic information from samples voluntarily donated by grandparents and other relatives of disappeared children, with the purpose of matching the genetic information of relatives with the genetic profiles of located children suspected of being offspring of the disappeared. Currently, the database contains genetic (DNA) information for 311 families (Penchaszadeh, 2012; MINCYT, 2013). While genetic testing initially relied on HLA and blood group anti- gen typing, DNA technology was soon incorporated, and the forensic genetics laboratory of the BNDG kept abreast with developments in the field. Currently, testing is based on the analysis of 15 short tandem repeats provided by the AmpF STRIdentifilerTM PCR Amplification kit (Applied Biosystems) and GeneMapper Software (Applied Biosystems), complemented when needed with mitochondrial DNA analysis, following guidelines from recognized international forensic genetic bodies (Bär et al., 1997; Carracedo et al., 2000; ICRC 2009). Genetic identification is deemed positive when the inclusion probability of an individual with unknown identity of being a grandchild of putative grandparents is $99.9 \%$ or higher.

\section{Results}

According to Argentina's law, the genetic testing of a minor suspected of being the victim of forced disappearance and suppression of identity is mandatory through the courts, with heavy involvement of psychology professionals, who care for the best interests of the child. When the true genetic identity of a disappeared child was determined, he/she was informed of the results and put in contact with the biological relatives, and the true identity of the individual was legally restored. Over time, as appropriated children became adults, nuances appeared in the process. First, adults who suspect they are the offspring of disappeared parents acquired the right to request genetic testing using the BNDG database through a special state agency (CONADI: Consejo Nacional por el Derecho a la Identidad) or through the courts. Second, the Supreme Court ruled in 2008 that when needed to uncover a crime of forced disappearance and suppression of identity, the state had the obligation of obtaining DNA for testing, and if the victim declined, DNA could still be obtained by non-invasive means (i.e., extracted from personal belongings, such as tooth brushes and underwear). Between July1984 and February 2014, 110 individuals appropriated as children and who had their identity suppressed, were genetically identified while they were still minors, or as adults, and their true genetic identity was recovered (Penchaszadeh, 2012).

\section{Discussion}

It is impossible to describe in depth the horrifying experiences of these 110 individuals who, at varying ages, were informed that they were not the children of those, who until then, they had considered as their parents. They came to know that their true parents had been murdered by dictatorship, that the appropriators who had raised them were in many instances directly or indirectly responsible for the disappearance and murder of their parents, that they were deceived consistently about their origin and ancestry, and that they had biological relatives who had been searching for them for decades. While the experiences of these children and young adults seemed shocking and terrible, most of these individuals expressed feelings of liberation and 
healing and of being energized when informed of their true identity after living in captivity with their appropriators for years.

Identified children and young adults reacted to the revelation of their true genetic identity in many different ways. A key factor was the age of the child at the time of disclosure and whether there existed loving and suitable biological relatives (usually grandparents) to take on the custody and rearing of the child after the restoration of identity. In general, younger children adjust well to the passage from a usually perverse rearing environment in the hands of appropriators to a loving and healing relationship with close relatives. Most individuals identified during childhood accepted their true identity with relief and with no evidence of psychological trauma from the process. However, young adults had diverse reactions, depending on whether testing had been decided voluntarily to solve their own doubts about their identity or initiated in the courts by biological relatives. However, the feelings of liberation and relief have been a common denominator, even for those whose initial reaction was denial and refusal of testing (Argento, 2008). In fact, many of these young men and women have eventually identified with the ideals of their disappeared parents, becoming activists for human rights and social justice. The following are interesting quotes from victims of identity suppression since birth:

María Eugenia Barragán-Sampalla, in the suit she filed against her appropriators said: "Can someone who stole a newborn, who concealed from her that she had been stolen, who might have disappeared or tortured her parents, who kept her away from them and her family, who always lied to her regarding her origin, who frequently mistreated, humiliated and deceived her, really feel parental love? My answer is no, that this type of relationship is marked by cruelty and perversion and not by love" (Vales, 2008; Elkin, 2008).

Victoria Donda, in her autobiography (Donda, 2009), uses the allegory of "as if my mother's genes were acting in me" to provide an explanation for why, even before knowing her true identity, her personality, political convictions, and social activism were so similar to her mother's. Regarding the difficulties of coming to grips with her true identity she stated: "Analía (her name as given by the appropriators) turned into Victoria (the name she was given by her mother at birth in the detention camp), without letting Analía go," as it took her a full year before deciding to undergo DNA tests, which confirmed her true identity. testing:

Alejandro Sandoval-Quintana, who initially rejected

"I fight for the same ideas that my parents fought, because that was passed to me through their DNA" (Sandoval-Fontana, 2010).

The last two quotations must be interpreted in the context of the extreme confrontation of the victims with the perverse objective of the military to suppress any traces of genetic identity in the appropriated children, rather than an assertion that genetics was the most important factor in determining their personal identity. In fact, all of those involved in this tragedy (victims, biological relatives, geneticists, psychologists and judges) acknowledged the fundamental role of emotional, educational, social, cultural and political factors in the conformation of their personal identity.

The search, localization, identification and restoration of the true genetic identity of the children of the disappeared is based on the notion that forced disappearance and suppression of identity are crimes against humanity (United Nations, 2007) and that the state has a legal responsibility for the actions of previous governments and is subject to the international law of human rights. The most important guiding ethical principle in this saga has been that of the value of the truth. Although most victims experienced psychological shock initially, knowledge of the truth, painful as it was, was emotionally liberating from the perversity, lies, concealment and violence that had surrounded their rearing.

\section{Restoration of the Genetic Identity of Missing People Subjected to the Compulsory Isolation of Leprosy Patients in Brazil}

\section{History of leprosy in Brazil}

Leprosy was introduced to America by European immigrants and the slave trade (Opromolla and Laurenti, 2011). In the late 1800s, the isolation of leprosy patients became public health policy in the United States, mainly due to the discovery of the bacillus that causes leprosy, Mycobacterium leprae, by GA Hansen in 1873. In Brazil, hospitals designed for leprosy patients were first established in the 1700s (White, 2003). Given Brazilian society's view of leprosy in the early twentieth century, patient segregation was considered the only way to protect the healthy. The Inspectorship for the Prevention of Leprosy and Venereal Diseases deemed isolation in leprosaria the preferred approach and enforced that policy (Cunha, 2010). The socalled São Paulo model, which was largely adopted in Brazil during the 20th century, was based on the trinity of leper asylum ("leprosário"), dispensary ("dispensário") and prevention center ("preventório"). Each of these institutions had its own distinct, albeit complementary, roles. The asylum was the most important for the isolation of the sick. The dispensary's role was to locate new patients and refer them for isolation. The role of the prevention center was to provide shelter for the healthy children of patients and all of the children born in the leper colonies, while keeping the children under close observation (Monteiro, 2003). Generally, the isolation of one of the parents led to a "familiar explosion" (Monteiro, 2003). If the children or spouse were infected, they all would be isolated together. However, their healthy children would be given to healthy 
relatives or be isolated in the prevention centers. The prejudice and fear from relatives of being contaminated or segregated because of these children increased the number of children referred to prevention centers. Similarly, children born inside leper colonies were immediately handed to relatives, given for informal adoption or isolated in the prevention centers. These children, identified as relatives of leprosy patients, were subjected to further discrimination by society in general, who avoided contact with them. Ultimately, the children were not allowed to leave the prevention center, not even to study outside, and could only attend primary school inside of the institution. Many of the children were put to work at a very early age (Monteiro, 2003). In 1960, there were 31 prevention centers formally established in Brazil (Ministerio da Saúde, 1960).

In the beginning of the 1940's, sulfones were shown to be an effective treatment for leprosy. A few months after treatment, patients had negative baciloscopic tests and became non-contagious. In Brazil, sulfones were successfully used in patients with leprosy as early as 1944 . However, until 1950 , the isolation of leprosy patients was maintained as a public health policy. The end of the mandatory isolation of patients in Brazil occurred in 1962 through a federal decree. However, in São Paulo, patients were admitted until 1967 (Opromolla and Laurenti, 2011). As a result of decades of the split family policy, many people currently do not know their parents or siblings or have no formal proof of their relationship.

At the beginning of the 1980's, the NGO Movement for the Reintegration of People Affected by Hansen's Disease (Morhan) started a campaign to search and identify people who had been separated from their kin. In 2012, the Brazilian Ministry of Health appointed an Internal Working Group to determine the number of people separated from their families and to provide them financial compensation (Movement for Reintegration of People Affected by Leprosy (Morhan), 2013). Morhan has registered 9,000 individuals who were separated as children from their parents due to compulsory isolation.

In 2011, the INAGEMP (National Institute of Science and Technology in Medical Population Genetics, CNPq) collaborated with Morhan to conduct DNA testing and to establish family links for individuals identified by the organization. The project was called "Reencontro", which means reunion.

\section{Methods}

In its first phase, INAGEMP tested only pairs or triplets of potential relatives, who were selected by their personal histories. All of the testing was completely voluntary and could be initiated by a formerly isolated individual who was looking for his/her relatives or by the relatives looking for someone who was isolated or separated from them in the past. Only presently living individuals were included in the study.
A thorough and comprehensive explanation about the test and potential limitations and risks was given in large meetings in the communities (meetings were assembled by Morhan) as well as in individual talks. Subjects were guaranteed that the sample obtained would be used only to establish family links and that the result would be confidential. A detailed questionnaire was applied to all of the subjects and including information regarding place of birth, colony-hospital, prevention center, circumstances of the separation, names of known relatives and adoptive family. A detailed family tree was constructed for each subject from different sources of information. Saliva samples were collected for DNA analysis.

Tests were performed only if all members of a possible family group agreed to give samples for testing and to provide written informed consent. They were also required to present an ID document, and a person from the research team witnessed the saliva collection to avoid any false identification.

To determine the probability of sibship, the AmpF STRIdentifilerTM PCR Amplification kit (Applied Biosystems) was used. The kit tested 15 short tandem repeat (STR) loci: D3S1358, TH01, D21S11, D18S51, D5S818, D13S317, D7S820, D16S539, CSF1PO, VWA, D8S1179, TPOX, FGA, D2S1338, D19S433, Penta E and Penta D. The results were analyzed using the ABI Prism 3130xl Genetic Analyzer (Applied Biosystems) and GeneMapper Software (Applied Biosystems). Genetic identification was deemed positive when the inclusion probability of an individual with unknown identity of being a brother/sister of putative siblings was $98.0 \%$ or higher.

Results were given to all of the individuals in written documents containing technical information, a probability of kinship and a lay explanation of the test and its result. The results were provided in person by the research team to enable verbal explanations and additional information if necessary.

\section{Results}

We tested 196 individuals from eight Brazilian states who presumed they had a sibling or a second-degree relative but had no legal proof of kinship. We confirmed a sibship relationship in 158 individuals with probabilities over $98 \%$. In two pairs, sibship was excluded; in another two cases, the probabilities of kinship were less than $80 \%$ and most likely represented half-siblings. The remaining cases were less evident, and they were presumably second-degree relatives (uncle/nephew, for example), as there were no other available living individuals to donate biological samples.

\section{Discussion}

The confinement of leprosy patients during the $20^{\text {th }}$ century was not restricted to Brazil, as it was policy practiced throughout the world, including the USA, where the 
Carville hospital in Louisiana acquired fame (White, 2003). The Carville model was adopted by other countries in Latin America where leprosy was endemic (Levinson, 2003; White, 2003; Leandro, 2013). Isolation as a health policy was implemented also in some countries in Europe (Cruz, 2009) and Asia (Robertson, 2009), such that families with a healthy member were segregated from sick relatives. We are aware of only one other project similar to ours, in Malaysia, which helps individuals separated from their families because of leprosy to regain their original identity through genetic identification. However, their data are only available on a website and not in a formal publication (http://blog.canpan.info/hansenbyo/archive/128).

Morhan has data on 9,000 individuals registered as separated from their families because of leprosy. We have tested only a small proportion of these individuals $(256$, or $2.9 \%$ ). While genetic testing is not needed for the majority of registered individuals because they have legal proof of their filiation, the program cannot help individuals with no living suspected relative, as we currently cannot offer genetic testing using samples from deceased persons.

In our limited perception, the most rewarding aspect of this project is to return the real identity to these individuals, allowing them to know their own history. Together, these individuals form a strong and empowered group trying to regain a dignity that was lost due to the stigmatization of people affected by Hansen's disease, which unfortunately was extended to their families.

\section{Conclusions}

The two experiences reported here have been very different. In Argentina, the military usurped power and imposed terror upon society to quell any dissent over their regressive economic policies. The main tools used to attain their objectives were forced disappearances, torture and the assassination of thousands of dissenters combined with the appropriation and suppression of the identity of hundreds of their offspring. The latter crime was particularly perverse, guided by hate and an ill-conceived idea of "social eugenics", which was directed not only at killing the dissenters but also at depriving society of their descendants. However, in Brazil, the suppression of identity of the children of patients with leprosy was a tolerated casualty of an ill-conceived and un-democratic health policy of the state, which erred in its aim of preventing the spread of the disease because of ignorance, historical prejudice, unwarranted fear of contagion, and stigmatization of the affected.

However, both experiences attest to the importance of forensic genetics as a tool for the defense of human rights, in particular the right to identity. Indeed, forensic genetics has been at the forefront of actions to repair egregious violations of human rights throughout the world, support the right of identity, bring those responsible to justice and heal the pain and suffering resulting from those violations (Doretti and Fondebrider, 2012; Paredes, 2012; Penchasza- deh, 2012; Ruiz-Figueroa, 2012). However, none of this would have been possible without the powerful social movements pressing for justice and human rights, which lead geneticists and social scientists to apply science for the benefit of the people.

The appropriated children of Argentina are now in their thirties, and those who have recovered their true genetic identity are essentially thrilled about it, even though this happened through a very painful process and with still-unknown long-term consequences for mental health and development. The feedback from the Brazil history indicates that personal identity is an essential human right and that most people will do everything possible to investigate and recover family relationships. As to the role of genetics in this endeavor, it is an important sign that the United Nations Council on Human Rights recently passed a resolution that declares forensic genetics a fundamental tool to investigate violations of human rights, such as the suppression of identity and forced disappearance (United Nations, 2009). Once again, it has been proven that science is not neutral and that it can be used either for good or bad causes. Geneticists should endeavor to prevent the abuses associated with genetics in the past (racism, stigmatization of the different, discrimination, genocide) and to associate our science only with actions that benefit humankind. At the same time, one should avoid the trap of genetic reductionism and acknowledge that genetic identity is only one dimension of personal identity, which is a complex phenomenon resulting from many factors, including those that are genetic, social, emotional, educational and political in nature.

\section{References}

Andersen ME (1993) Dossier Secreto: Argentina's Desaparecidos and the Myth of the "Dirty War". Westview Press, Boulder, $412 \mathrm{pp}$.

Argento, A (2008) De Vuelta a Casa: Historias de Hijos y Nietos Restituídos. Marea Editorial, Buenos Aires, 254 pp.

Bär W, Brinkmann B, Budowle B, Carracedo A, Gill P, Lincoln P, Mayr W and Olaisen B (1997) DNA recommendations. Further report of the DNA Commission of the ISFG regarding the use of short tandem repeat systems. Forensic Sci Int 87:179-184.

Carracedo A, Bär W, Lincoln P, Mayr W, Morling N, Olaisen B, Schneider P, Budowle B, Brinkmann B, Gill P, et al. (2000) DNA Commission of the International Society for Forensic Genetics: Guidelines for mitochondrial DNA typing. Forensic Sci Int 110:79-85.

CONADEP (1986) Comisión Nacional Sobre Desaparición de Personas. Nunca Más.

Cruz A (2009) O Hospital-Colónia Rovisco Pais: a última leprosaria portuguesa e os universos contingents da experiência e da memória. Hist Ciênc Saúde 16:407-431.

Cunha VS (2010) Isolated 'like us' or isolated 'among us'?: the controversy within the National Academy of Medicine over compulsory isolation of leprosy sufferers. Hist Ciênc Saúde 17:939-954. 
Di Lonardo AM, Darlu P, Baur M, Orrego C and King MC (1984). Human genetics and human rights: identifying the families of kidnapped children. A J Forensic Med Pathol 5:339-347.

Donda, V (2009) Mi Nombre es Victoria: Una Lucha por la Identidad (My Name is Victoria: A Struggle for Identity). Editorial Sudamericana, Buenos Aires, 256 pp.

Doretti M and Fondebrider L (2012) La Iniciativa Latinoamericana para la Identificación de Desaparecidos (ILID): Identificación científica de restos de personas desaparecidas. In: Penchaszadeh VB (ed) Genética y Derechos Humanos. Paidós, Buenos Aires, 299-328 pp.

Kevles DJ (1995) In the Name of Eugenics. Harvard University Press, Cambridge, $426 \mathrm{pp}$.

Leandro JA (2013) Em prol do sacrifício do isolamento: Lepra e filantropia na Argentina e no Brasil, 1930-1946. Hist Ciênc Saúde 20:913-938.

Levinson JH (2003) Beyond quarantine: A history of leprosy in Puerto Rico, 1898-1930s. Hist Ciênc Saúde 10(suppl 1):225-245.

Ministério da Saúde (1960) Manual de Leprologia. Editora Serviço Nacional de Lepra, Rio de Janeiro, 20 pp.

Monteiro YN (1998) Violência e profilaxia: os preventorios paulistas para filhos de portadores de hanseniase. Saúde Soc 7:3-26.

Monteiro YN (2003) Prophylaxis and exclusion: Compulsory isolation of Hansen's disease patients in São Paulo. Hist Ciênc Saúde 10(suppl 1):95-121.

Müller-Hill B (1988) Murderous Science. Elimination by Scientific Selection of Jews, Gypsies and others, Germany 19331945. Oxford University Press, Oxford, 256 pp.

OAS Organization of American States (1978) Report on the Situation of Human Rights in Argentina. Organization of American States, Washington DC, $83 \mathrm{pp}$.

Opromolla PA and Laurenti R (2011) Hansen's disease control in the State of São Paulo: a historical analysis. Rev Saude Publica 45:1-7.

Paredes M (2012) El papel de la genética forense en la investoigación de violaciones a los derechos humanos y al derecho internacional humanirtario en Colombia. In: Penchaszadeh VB (ed) Genética y Derechos Humanos. Paidós, Buenos Aires, pp 357-368.

Penchaszadeh VB (1997) Genetic identification of children of the disappeared in Argentina. J Am Med Women's Assoc 52:16-27.

Penchaszadeh VB (2012) Uso de la identificación genética en la reparación de la violación del derecho a la identidad durante la dictadura militar argentina. In: Penchaszadeh VB (ed) Genética y Derechos Humanos. Paidós, Buenos Aires, pp 263-298.

Robertson J (2009). The leprosy asylum in India: 1886-1947. J Hist Med Allied Sci 64:474-517.

Ruiz-Figueroa V (2012) Chile: La ciencia al servicio de la investigación, la justicia y la reparación. In: Penchaszadeh VB (ed) Genética y Derechos Humanos. Paidós, Buenos Aires, pp 329-356.

Van Boven, T (1988) The disappearance of children in Argentina. Report to the United Nations Commission of Human Rights. August 10. Document E/CN.4/Sub.2/1988/19. UNCHR: Geneva. Quoted in: Lawson E (ed) Encyclopedia of Human Rights. Washington, DC, Taylor and Francis, p 101.
White C (2003) Carville and Curupaiti: Experiences of confinement and community. Hist Ciênc Saúde 10(suppl 1):123141.

\section{Internet Resources}

CONADEP (1986) Commission on the Disappearance of Persons. Nunca Más! (Never Again!). http://www.desaparecidos.org/nuncamas/web/english/library/nevagain/nevagain_001.htm (Accessed February 7, 2014).

Elkin M (2008) Maria Barragán Succeeds in Getting Adoptive Parents Jailed. The Times Online, April 5, 2008, http://www.timesonline.co.uk/tol/news/world/us_and americas/article3687055.ece (Accessed February 4, 2014).

ICRC (2009) International Committee of the Red Cross. Missing people, DNA Analysis and Identification of Human Remains -a guide to best practice in armed conflicts and other situations of armed violence-, ICRC, Geneva, http://www.scribd.com/doc/25043823/Missing-people-DN A-analysis-and-identification-of-human-remains-a-guide- $t$ o-best-practice-in-armed-conflicts-and-other-situations-ofarmed-violence (Accessed February 4, 2014).

MINCYT (2013). Ministerio de Ciencia, Tecnología e Innovación Productiva, Argentina. El Banco Nacional de Datos Genéticos.

http://www.mincyt.gob.ar/ministerio/banco-nacional-de-da tos-geneticos-bndg-23 (Accessed February 4, 2014).

Movement for Reintegration of People Affected by Leprosy (Morhan). http://www.morhan.org.br/views/upload/relfilhossep.pdf (Accessed December 25, 2013).

Sandoval-Fontana A (2010). Quoted in: Forero J. Orphaned in Argentina's Dirty War, Man Is Torn between Two Families. Washington Post, February 11, 2010. http://www.washingtonpost.com/wp-dyn/content/article/2010/02/10/AR2010021003662.html (Accessed 5 February 2014).

United Nations (1989). Convention of the Rights of the Child. http://www.unicef.org.uk/Documents/Publication-pdfs/UNCRC_PRESS200910web.pdf (Accessed February 4,2014$)$.

United Nations (2007) International Convention for the Protection of All Persons from Enforced Disappearance, adopted by the UN General Assembly. (Article 2) 20th December. United Nations, Available in: https://treaties.un.org/doc/source/RecentTexts/IV_16_english.pdf? (Accessed February 4, 2014).

United Nations (2009) Resolution on the use of forensic genetics in cases of serious violations of human rights. UN Council of Human Rights, A/HRC/10/L.36. United Nations, http://ap.ohchr.org/documents/E/HRC/resolutions/A_HRC_RES_10_26.pdf (Accessed February 4, 2014).

Vales, L (2008) Apropiadores de María Eugenia Barragán sentenciados a 8 y 9 años de cárcel. Una condena por "un vínculo cruel y perverso" Pagina 12, April 5th. http://www.pagina12.com.ar/diario/principal/index-2008-04-05.html (Accessed February 5, 2014).

License information: This is an open-access article distributed under the terms of the Creative Commons Attribution License, which permits unrestricted use, distribution, and reproduction in any medium, provided the original work is properly cited. 